\title{
ISLAM DAN PEMBERDAYAAN MASYARAKAT PERSPEKTIF HADIS
}

\author{
Sobirin Bagus \\ sobirin.bagusbanget2020@ gmail.com \\ Progrom Doktoral Pascasarjana UNISMA, Malang
}

\begin{abstract}
The purpose of this paper is to make an inventory of the hadiths of the prophet relating to community empowerment, to know his takhrij, and to examine the contents of the hadiths about community empowerment. The method used is a thematic method with a literature research approach by examining the hadiths from capital sources. The conclusion is that the results of an inventory of the hadiths about community empowerment were obtained 129 hadiths from 18 hadith books. Of these 129 hadiths, the writer takes the most relevant hadiths, namely the hadith from Abud Daud Number 1398 on economic empowerment and the hadith from Abu Daud number 18723. Community economic empowerment during the time of the prophet is in the hadith of Abu Daud, while the empowerment of Ahmad's hadith. Meanwhile, community empowerment during the caliphate: education, monotheism, morals, worship, health. The Caliphate then built mosques, appointed teachers, taught the contents of the Al-Quran and other Islamic teachings. The next caliphate: the freedom to teach according to the desired place. And the last Caliphate focused on security and peace. The relevance of community empowerment in educational institutions is very clear amid diversity but it is not yet maximally and evenly distributed. Both in terms of community empowerment in the field of science and community empowerment in the field of economy and welfare.
\end{abstract}

Key Word: community empowerment, hadith perspective, Islam

\begin{abstract}
Abstrak
Tujuan tulisan ini adalah menginventarisir Hadis-Hadis nabi berkaitan dengan pemberdayaan masyarakat, mengetahuu takhrijnya, serta mengkaji isi kandungan dari Hadis tentang pemberdayaan masyarakat. Metode yang digunakan adalah metode tematik dengan pendekatan penelitian kepustakaan dengan mengkaji Hadis-Hadis dari sumber aslinya. Kesimpulannya adalah hasil menginventarisir HadisHadis tentang pemberdayaan masyarakat maka didapatkan 129 Hadis dari 18 kitab Hadis. Dari 129 Hadis tersebut penulis mengabil Hadis yang paling relevan yaitu Hadis dari Abud Daud Nomor 1398 tentang pemberdayaan ekonomi dan Hadis dari Abu Daud nomor 18723. Pemberdayaan ekonmi masyarakat pada masa nabi tercermin dalam Hadis Abu Daud, sedangkan pemberdayaan ilmu dalam Hadis Ahmad. Sedangkan pemberdayaan masyarakat masa kekhalifahan: pola pendidikan, materi pendidikan, dan lembaga pendidikan, pendidikan Islam, tauhid, akhlak, ibadah, kesehatan. Kekhalifahan selanjutnya membangun masjid, menunjuk guru-guru, mengajarkan isi Al Qur'an dan ajaran Islam lainnya. Kekhalifahan selanjutnya: adanya kebebasan untuk mengajar sesuai tempat yang diinginkan. Dan kekhalifahan yang terakhir berfokus pada keamanan dan kedamaian. Sedangka relevansi pemberdayaan masyarakat di lembaga pendidikan sudah sangat jelas dijumpai ditengah tengah keberagaman namun belum secara maksimal dan merata. Baik dalam hal pemberdayaan masyarakat di bidang penguatan ilmu pengetahuan maupun pemberdayaan masyarakat di bidang ekonomi dan kesejahteraan.
\end{abstract}

Kata Kunci: Islam, pemberdayaan masyarakat, perspektif hadis,

\section{PENDAHULUAN}

Islam dan masyarakat tidak bisa dipisahkan karen Islam sebagai agama dan masyarakat sebagai pemeluknya. Pemberdayaan merupakan sesuatu yang harus dilakukan karena merupakan bagian dari konsep ketuhanan dan konsep kemanusiaan 
dengan kata lain hablun minalloh wa hablun minannas. Dalam konsep ketuhanan misalnya masyarakat melakukan shalat sementara dalam konsep kemanusiaan masyarakat melakukan zakat infak shodaqoh. Itulah yang sering kita jumpai kata-kata "dan dirikanlah shalat dan tunaikanlah zakat."1 Dengan demikian maka setiap masyarakat hendaknya membangun kepedulian sosial. Dengan terbangunnya kepedulian sosial tersebut maka akan semakin mudah dalam pemberdayaan masyarakat. Pada wilayah kemanusiaan, setiap manusia yang memiliki daya, memiliki kewajiban secara sosial untuk tidak membedakan manusia-manusia lainnya yang berada dalam kondisi ketidak mampuan, apalagi di bidang Ekonomi. Disinilah perlunya pemberdayaan masyarakat dengan cara saling menolong. Sikap saling menolong merupakan salah satu kepribadian seorang muslim dan merupakan budaya yang dilestarikan di dalam Islam. ${ }^{2}$

Sementara pemberdayaan masyarakat berarti aktivitas seseorang dalam pemantauan kehidupannya sendiri serta berusaha menata masa depan bersamaan dengan kemampuannya sendiri. ${ }^{3}$ Pemberdayaan masyarakat berarti merupakan rangkaian pensejahteraan orang banyak sesuai dengan kebutuhannya. ${ }^{4}$ Seseorang tidak bisa hidup tanpa orang lain, demikian juga halnya dengan keluarga, kelompok organisasi, dan masyarakat. Nilai-nilai sosial dalam pemberdayaan masyarakat memang harus ditunjukkan oleh setiap individu untuk mewujudkan solidaritas antar sesama. ${ }^{5}$ Dalam dalam rangka memenuhi kebutuhan hidup maka manusia perlu bekerjasama dengan orang lain, perlu merancang rencana dalam proses pemenuhan kebutuhan. Pada saat yang sama pemerataan kesejahteraan yang dilakakukan oleh pemerintah belum dapat dikatakan merata sehingga masyarakat perlu diberdayakan dalam ruang-ruang organisasi kemasyarakatan.

Pemberdayaan masyarakat dalam lingkup masyarakat kaitannya dengan Islam bukan hanya merupakan sesuatu yang bersifat asing. Nabi Muhammad sebagi suri

\footnotetext{
${ }^{1}$ Abdul Azis Al Fauzan, Fikih Sosial: Tuntunan dan Etika Hidup Bermasyarakat, terjemahan Iman Firdaus dan Ahmad Salahudin (Jakarta Timur: Qisthi Press, 2007), 300.

2 Imam Baihaki, "Potret Penguburan Janazah Dalam Islam Merupakan Bentuk Kepedulian Sosial DuniaAkhirat," Al Bayan: Jurnal Ilmu Al Qur'an dan Hadist 4, no. 1 (2021): 67-77.

${ }^{3}$ Isbandi Rukminto Adi, Pemberdayaan, pengembangan masyarakat dan Intervensi Komunitas (Jakarta: Lembaga Penerbit FEUI, 2003), 33.

${ }^{4}$ Effendy Nasrul, Dasar-dasar keperawatan kesehatan masyarakat (Jakarta: EGC, 1998), 9.

${ }^{5}$ Wely Dozan, "Hadis-Hadis Tahlilan: Analisis Konflik dan Nilai-Nilai Sosial Masyarakat," Al Bayan: Jurnal Ilmu Al Qur'an dan Hadist 3, no. 2 (2020): 195-211.
} 
taudalan bagi manusia bahwasanya telah mempraktikkan tentang pemberdayaan masyarakat. Demikian juga yang dilakukan oleh ulama-ulama dahulu sampai pada kiyai kontemporer bahwa mereka akan mendidik para santrinya untuk mewujudkan kebersmaan dalam memberdayakan masyarakat dan ia akan hadir di tengah-tengah masyarakat untuk mencapai tujuan bersama. ${ }^{6}$

Seorang muslim harus kuat dalam menghadapi segala bentuk tantangan hidup. Kuat secara fisik, kuat secara ilmu, dan kuat secara ekonomi. Ketika kekuatan-kekuatan tersebut belum dapat dimaksimalkan secara individu maka diperlukan pemberdayaan untuk mengakomodir kekuatan kekuatan tersebut sehingga mendapatkan hasil yang maksimal. Bukankah setiap perintah dan larangan dalam agama ini cenderung menggunakan dhomir hum yang artinya perintah untuk orang banyak. Maka pemberdayaan masyarakat dalam Islam ini perlu untuk dikaji lebih mendalam dalam perspektif Hadis nabi Muhammad SAW.

Penelitian tentang pemberdayaan masyarakat sudah pernah diteliti oleh Abd. Wahid HS. Dalam melakukan pemberdayaan, Al-Qur'an mengatur sesuai prinsipprinsip baku syari'at yang berupa taqlilut takalif (mempersedikit pembebanan), 'adamul harji (menghilangkan kemelaratan), dan at-tadarruj fit-tasyri' (perlahan-perlahan dalam memberikan hukum), Al-Qur'an juga melakukannya dengan prinsip-prinsip yang lain yaitu: Mempermudah media dan cara penyampaian. Perhatian lebih kepada mereka yang belum paham. Persamaan dakwah dan kesetaraan status sosial. ${ }^{7}$

Dari kedua hasil penelitian diatas bahwa keduanya membahas tentang pemberdayaan masyarakat secara umum serta menggunakan perspektif al-Qur'an dan sejarah kejayaan Islam pada masa lampau, memaparkan tentang prinsip-prinsip pemberdayaan menurut al-Qur'an. Dari kedua penelitian tersebut penulis mencoba membahas pemberdayaan masyarakat yang lebih mengerucut pada pemberdayaan ilmu pengetahuan dan pemberdayaan ekonomi sehingga diharapkan mampu menjawab dan memberikan solusi untuk penguatan pemberdayaan ilmu pengetahun dan penguatan pemberdayaan ekonomi masyarakat. Tulisan ini akan membahas tentang Islam dan pemberdayaan masyarakat dalam perspektif Hadis. Tujuan tulisan ini adalah

\footnotetext{
${ }^{6}$ Mia Kurniati, "Peran Kepemimpinan Kyai Dalam Mendidik Dan Membentuk Karakter Santri Yang Siap Mengabdi Kepada Masyarakat," Al Bayan: Jurnal Ilmu Al Qur'an dan Hadist 2, no. 2 (2019): 193-202.

${ }^{7}$ Ulfi Putra Sany, "Prinsip-Prinsip Pemberdayaan Masyarakat Dalam Perspektif Al Qur'an," Jurnal Ilmu Dakwah 39, no. 1 (2019): 32-44.
} 
menginventarisir Hadis-Hadis nabi berkaitan dengan pemberdayaan masyarakat, mengetahui takhrijnya, serta mengkaji isi kandungan dari Hadis tentang pemberdayaan masyarakat. Metode yang digunakan adalah metode tematik dengan pendekatan penelitian kepustakaan dengan mengkaji Hadis-Hadis dari sumber aslinya.

\section{PEMBAHASAN}

\section{Inventarisasi hadis-hadis tentang Islam dan Pemberdayaan Masyarakat}

Penginventarisasi Hadis tentang Islam dan pemberdayaan masyarakat ini menggunakan https://carihadis.com/ dengan kata kunci masyarakat. Hasilnya terdapat 129 Hadis yang terdapat di dalam 18 kitab Hadis yang terdapat kata masyarakat didalamnya. Dari hasil inventarisir Hadis yang berjumlah 129 Hadis maka penulis memilih beberapa Hadis yang paling relevan dengan tema pemberdayaan masyarakat. Diantaranya yaitu Hadis yang terdapat dalam Sunan Abud Daud nomor 1398 tentang pemberdayaan ekonomi, serta Musnad Ahmad 18723 tentang pemberdayaan Ilmu.

\section{Kajian takhrij al-Hadis untuk meneliti kualitas sanad dan matan hadis}

Takhrij Hadis ditinjau dari segi etimologi bermakna menampakkan, menumbuhkan, menampakkan, menyebutkan, mengeluarkan. Sedangkan menurut termonologi takhrij Hadis menyampaiakn Hadis secara lengkap dengan riwayat asal serta menunjukkan sumber dan letak aslinya. ${ }^{8}$

Adapun metode dalam mentakhrij Hadis antara lain: a) Takhrij dengan kata b) Takhrij dengan tema c) Takhrij dengan awal matan d) takhrij dengan sanad pertama e) Takhrij dengan sifat Hadis. ${ }^{9}$ Dari sekian banyak metode takhrij yang ada, penulis mencoba mentakhrij Hadis menggunakan metode dengan kata. Kata kunci yang digunakan adalah masyarakat.

Sanad adalah jalan penghubung dari matan Hadis sampai kepada nabi Muhammmad SAW. sanak juga dapat digunakan sebagai instrumen untuk menentukan nilai Hadis, karena suatu Hadis dikatakan shahih salah satunya adalah apabila sanadnya

\footnotetext{
${ }^{8}$ M Syuhudi Ismail, Metodologi Penelitian Hadis Nabi (Jakarta: PT. Bulan Bintang, 1992), 41.

${ }^{9}$ Abdul Majid Khon, Ulumul hadis (Jakarta: Amzah, 2012), 119.
} 
bersambung sampai kepada Rasulullah SAW. ${ }^{10}$ Matan adalah merupakan isi riwyat yag terletash setelah sanad. ${ }^{11}$

\section{Sunan Abu Daud}

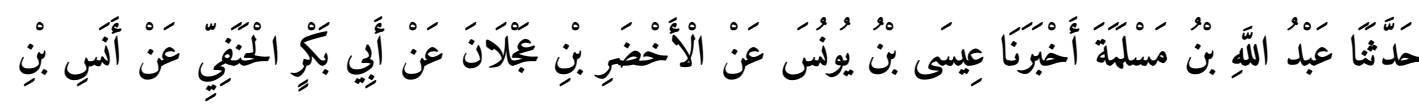

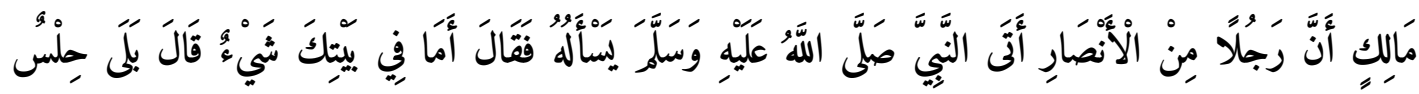

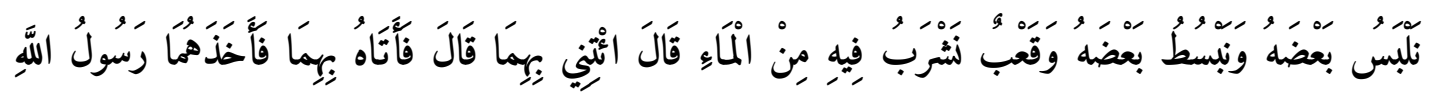

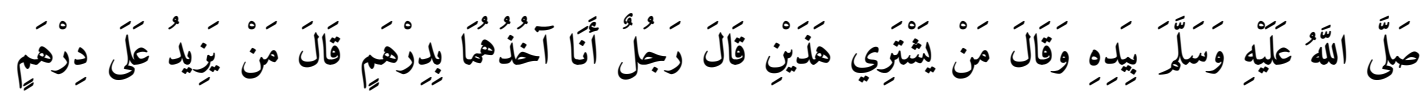

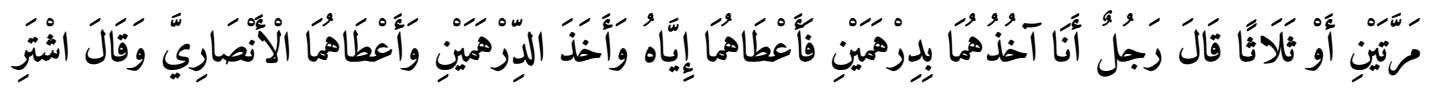

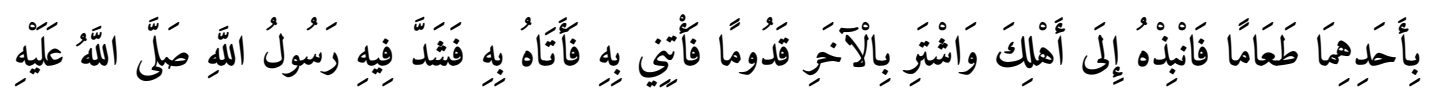

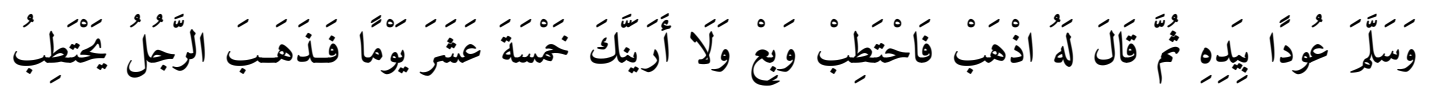

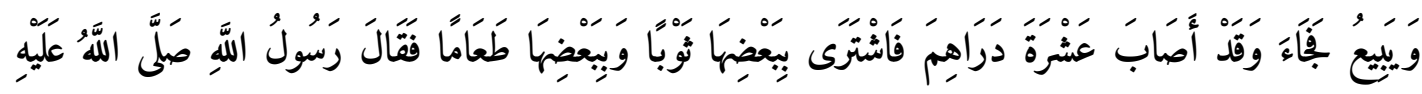

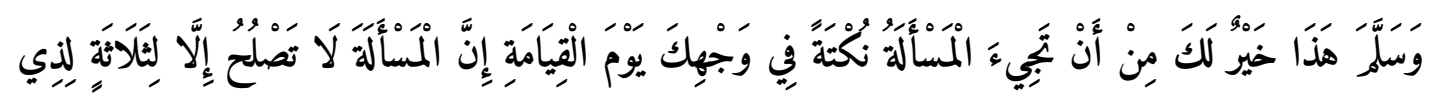

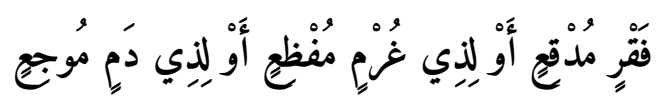

"Telah menceritakan kepada Kami Abdullah bin Maslamah, telah mengabarkan kepada Kami Isa bin Yunus dari Al Akhdhar bin 'Ajlan dari Abu Bakr Al Hanafi dari Anas bin Malik bahwa seorang laki-laki dari kalangan Anshar datang kepada Nabi shallallahu 'alaihi wasallam meminta kepada beliau, kemudian beliau bertanya: "Apakah di rumahmu terdapat sesuatu?" Ia berkata; ya, alas pelana yang Kami pakai sebagiannya dan Kami hamparkan sebagiannya, serta gelas besar yang gunakan untuk minum air. Beliau berkata: "Bawalah keduanya kepadaku." Anas berkata; kemudian ia membawanya kepada beliau, lalu Rasulullah shallallahu wa'alaihi wa sallam mengambilnya dengan tangan beliau dan berkata; "Siapakah yang mau membeli kedua barang ini?" seorang laki-laki berkata; saya membelinya dengan satu dirham. Beliau berkata: "Siapa yang menambah lebih dari satu dirham?" Beliau mengatakannya dua

\footnotetext{
${ }^{10}$ Fatchur Rahman, Ikhtisar Musthalahul Hadis (Bandung: PT. AL-Ma'arif, 1974), 177.

${ }^{11}$ Muhammad S Rahman, "Kajian Matan dan Sanad Hadis dalam Metode Historis," Jurnal Ilmiah AlSyir'ah 8, no. 2 (2016).
} 
atau tiga kali. Seorang laki-laki berkata; saya membelinya dengan dua dirham. Kemudian beliau memberikannya kepada orang tersebut, dan mengambil uang dua dirham. Beliau memberikan uang tersebut kepada orang anshar tersebut dan berkata: "Belilah makanan dengan satu dirham kemudian berikan kepada keluargamu, dan belilah kapak kemudian bawalah kepadaku." Kemudian orang tersebut membawanya kepada beliau, lalu Rasulullah shallallahu wa'alaihi wa sallam mengikatkan kayu pada kapak tersebut dengan tangannya kemudian berkata kepadanya: "Pergilah kemudian carilah kayu dan juAllah. Jangan sampai aku melihatmu selama lima belas hari." Kemudian orang tersebut pergi dan mencari kayu serta menjualnya, lalu datang dan ia telah memperoleh uang sepuluh dirham. Kemudian ia membeli pakaian dengan sebagiannya dan makanan dengan sebagiannya. Kemudian Rasulullah shallallahu wa'alaihi wa sallam bersabda: "Ini lebih baik bagimu daripada sikap meminta-minta datang sebagai noktah di wajahmu pada Hari Kiamat. Sesungguhnya sikap memintaminta tidak layak kecuali untuk tiga orang, yaitu untuk orang fakir dan miskin, atau orang yang memiliki hutang sangat berat, atau orang yang menanggung diyah (sementara ia tidak mampu membayarnya"). ${ }^{12}$

Sumber Hadisnya adalah dari Abu Daud dalam kitab Zakat bab kapan seseorang boleh meminta, dengan nomor Hadis 1398. Jalur Sanad Hadis ini dari Anas bin Malik an Nadlir bin Dlamdlom bin Zaid bin Haram ke Abdullah ke Al Ahdlor bin a'jlan ke Isa bin Yunus bin Abi Ishaq ke Abdullah bin Maslamah bin Qa'nab. Kesimpulan hukum para muhaddits adalah Hadis ini dha'if (Isnaduhu Dha'ifun).

\section{Musnad Ahmad}

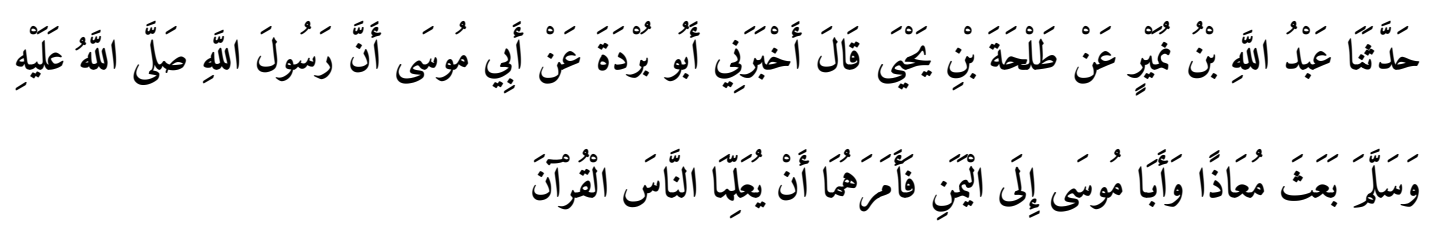

Artinya : "Telah menceritakan kepada kami Abdullah bin Numair dari Thalhah bin Yahya ia berkata, telah mengabarkan kepadaku Abu Burdah dari Abu Musa bahwa Rasulullah shallallahu 'alaihi wasallam mengutus Mu'adz dan Abu Musa ke negeri Yaman. Maka beliau memerintahkan kepada keduanya untuk mengajarkan Al Qur'an kepada masyarakat". ${ }^{13}$

\footnotetext{
12 https://carihadis.com/Sunan_Abu_Daud/1398, t.t.

${ }^{13}$ https://carihadis.com/Musnad_Ahmad/18723, t.t.
} 
Sumber Hadisnya dari Musnad Ahmad dalam kitab Musnad, dengan nomor Hadis 18723. Jalur Sanadnya dari Abdullah bin Qais bin Sulaiman bin Hadldlor ke Amir bin 'Abdullah bin Qais ke Thalhah bin Yahya bin 'Ubaidillah ke Abdullah bin Numair. Kesimpulan Takhrij Sanadnya Hasan. Hadis riwayat Ahmad, dan lafadz yang sama ada di Tabrani 20/43 (66) lafadz yang ebih panjang ada di riwayat Al-Hakim 2084 dengan perbedaan yang tidak terlalu banyak.

\section{Kajian tentang kandungan hadis}

\section{Metode dan Interpretasi para ulama hadis dalam kitab-kitab syarah hadis}

Agama Islam merupakan agama yang peduli kepada masyarakat miskin. Islam mendorong pemeluknya untuk keluar dari kemiskinan. Bahkan tidak sampai disitu akan tetap Islam memberikan perintah kepada pemeluknya untuk saling membantu supaya orang miskin bisa keluar keluar dari kemiskinan dengan zakat infaq dan shodaqoh.

Berkaitan dengan Islam dan pemberdayaan masyarkat maka penulis membatasi pemberdayaan masyarakat dalam pemberdayaa ekonomi dan pemberdayaan Ilmu. Dalam hal pemberdayaan ekonomi maka Rasulullah lah yang patut untuk kita ikuti dalam pemberdayaan ekonomi masyarakat. Begitu juga dengan pemberdayaan ilmu maka Rasulullah Muhammad SAW yang patut dijadikan contoh dalam pemberdayaan Ilmu.

a. Sunan Abu Daud

Salah satu Hadis yang menggambarkan bagaimana Rasulullah SAW dalam pemberdayaan ekonomi adalah Hadis yang terdapat di dalam Sunan Abu Dawud nomor 1398. Hadit diatas terlihat bahwasanya orang miskin yang sendiri yang tidak punya akses terhadap masyarakat akan sulit keluar dari kemiskinannya. Ketika orang anshor tersebut datang dan meminta sesuatu maka Rasulullah tidak lansung memberikannya akan tetapi menyadarkan orang tersebut sambil memberi pendampingan untuk keluar dari kesusahan dan kemiskinan.

Rasulullah bertanya perihal keperluan orang anshor tersebut. Setelah orang anshor tersebut menjawab pertanyaan nabi, lalu raslullah SAW berkata menyuruhnya untuk mengambil barang dan membawanya ke hadapan rasulullah. Disini kita melihat bagaimana keliahan Rasulullah Muhammad SAW dalam mengasesment dan melakukan mapping point terhadap orang anshor tersebut untuk memberikan kesadaran supaya ia 
sadar akan potensinya. Supaya dia sadar bahwa ada Allah SWT yang maha kaya. Semiskin apapun yang dialami oleh sahabat anshor tersebut tetap ia memiliki potensi untuk keluar dari kemiskinan. Karen uang bukanlah segalanya.

Setelah dialog tersebut kemudia orang anshor tersebut pulang kerumahnya untuk mengambil barang yang diminta oleh rasulullah dan bahkan mungkin saja itu adalah barang satu satunya yang dimilikinya. Kemudian rasulullah mengambilnya dan melelangnya.

Disini Rasulullah SAW menawarkan barang milik orang anshor tersebut kepada sahabat-sahabat yang lain "Siapakah yang mau membeli kedua barang ini?". Ketika ada sahabat yang menawar rasulullah menawarkan kepada sahabat yang lain yang mau membeli barang tersebut meleibihi sahabat sebelumnya, dan begitu terus sampai mendapatkan harga yang cocok. Berarti disini Rasulullah SAW melakukan lelang terhadap barang orang anshor yang meminta sesuatu kepada nabi tersebut. Poinnya berarti Nabi mengajarkan kepada kita untuk mengubah aset yang ada dan tidak produktif menjadi aset yang produktif.

Apabila seorang anshor tersebut melakukannya sendiri maka dia tidak akan mampu karna itulah disini diajarkan oleh Nabi untuk bagaimana mengubah aset menjadi produktif yaitu dengan pemberdayaan yang bisa dilakukan oleh organisasi tertentu atau pribadi tertentu yang mempunyai akses lebih luas. Dukungan akses yang lebih luas inilah yang dapat membantu seseorang menjadi lebih produktif dan keluar dari kemiskinan.

Ketika hasil penjualan barang orang anshor tersebut laku maka Rasulullah SAW memberikan kepada orang anshar tersebut dengan berbesan pergilah beli makanan dan kampak. Makanan itu diberikan kepada keluarganya dan kampak berikan kepada rasulullah. Disini rasulullah mengajarkan untuk memenej keuangan sebaik baiknya, dari hasil lelang itu tidak dibelanjakan semua untuk keperluan makan tapi hendaknya dibelanjakan secukupnya kemudian digunakan untuk modal berusaha. Dengan disuruhnya orang anshor tersebut membeli kampak maka kampak inilah yang akan menjadi modal orang anshor tersebut berusaha.

Ketika orang anshor tersebut kembali kepada rasulullah dengan membawa kampak, rasul membuatkan pegangan pada kampak tersebut supaya bisa digunakan. Setelah kampak tersebut mempunyai peganagan dan sudah bisa digunakan maka rasul 
berkata: "Pergilah kemudian carilah kayu dan juallah. Jangan sampai aku melihatmu selama lima belas hari". Rasul memerintahkannya untuk cari kayu bakar yang kemudian hasilnya bisa dijual sehingga orang anshor itu punya pekerjaan sendiri, bisa mencukupi ekonomi keluarganya tanpa harus meminta minta. Rasulullah juga tidak ingin melihat orang anshor tersebut selama 15 hari, artinya untuk keluar dari kemiskinan itu butuh proses. Setelah 15 hari barulah orang anshor kembali kepada rasulullah sesuai perintahnya.

Hikmah dari Hadis tersebut yaitu didapatkan teknik pemberdayaan ekonomi masyarakat dengan cara : 1. Sadarkan pentingnya pemberdayaan ekonomi masyarakat, 2. Sosialisasikan bahwa modal uang bukanlah hal yang utama, 3. Lihat potensi masyarakat, 4. Ubah aset yang tidak produktif, 5. Sediakan wadah pemasaran, 6. Transparan dan atur keuangan dengan baik, 7. Tunjuk pendampingan usaha yang profesional 8. Efektifkan waktu, 9. Motivasi untuk berubah.

b. Musnad Ahmad

Hadis yang bersumber dari Imam Ahmad yang bercerita tentang Rasuluullah SAW mengutus Muadz dan Abu musa ke yaman. Sumbernya hadisnya adalah dari Musnad Ahmad, dengan nomor Hadis 18723. Jalur Sanad Hadis ini dari Abdullah bin Qais bin Sulaiman bin Hadldlor ke Amir bin 'Abdullah bin Qais ke Thalhah bin Yahya bin 'Ubaidillah ke Abdullah bin Numair.

Rasulullah SAW megutus Muadz dan Abu Musa ke Yaman untuk mengajarkan Al-Qur'an kepada masyarakat di Yaman. Titik kaji dari Hadis ini adalah pemberdayaan masyarakat dalam kaitannya dengan pemberdayaan di bidang ilmu pegetahuan. Hal penting yang harus dipahami adalah tanggung jawab pengajaran Al-Qur'an kepada masyarakat yaman adalah berada di pundah Muadz dan Abu Musa.

Jika dibawa ke zaman sekarang maka perlu difahami bahwa tanggung jawab untuk mengajarkan Al-Qur'an itu berada di pundak para guru, para ustadz, para orang tua, para da'i, para imam di setiap tempat dan di setiap zaman. Tanggung jawab tersebut bukanlah tanggung jawab yang mudah dan remeh, hal tersebut terlihat dari tidak pedulian pada generasi berikutnya untuk belajar Qur'an. Pembelajaran Al-Qur'an hanya sebatas pelaran yang satu kali satu minggu dilakukan di sekolah atau satu jam saja di sore hari di Masjid Masji. 
Seseorang yang telah mengproklamirkan dirinya sebagai seorang muslim maka tidak cukup hanya mengatakan keislamannya, namu tidak dibarengi dengan perbuatan yang mencerminkan akhlak islami. Bahkan tidak cukup hanya melakukan perbuatan baik hanya untuk dirinya sendiri saja. Maka harus dibarengi dengan amar makruf kepada khalayak orang banyak atau kepada masyarakat sekitarnya.

\section{Kaitan Pemberdayaan Masyarakat Masa Nabi \& Masa Kekhilafahan Islam}

a. Pemberdayaan Masyarakat Masa Nabi dan Masa Kekhalifahan Islam

Pemberdayaan masyarakat masa nabi Muhammad SAW sudah pernah terjadi bahkan dalam banyak model dan bentuk. Salah satunya adalah kisah laki-laki dari kalangan ansor yang meminta sesuatu kepada Rasulullah. Maka disini rasulullah tidak lansung memberikan apa yang diminta dan apa yang dibutuhkan oleh laki-laki tersebut, namun rasulullah malah bertanya kepada laki-laki tersebut tentang apa saja barang yang ada dirumahnya selain yang digunakan olehnya dan yang digunakan oleh keluarganya dirumah. Dalam riwayat tersebut kemudia mengungkapkan sebuah kisah tentang bagaimana kebijaksanaan rasul dalam memberdayakan masyarakat. Tidak memberi sesuatu kepada peminta-minta namun mencari sesuatu yang berharga pada diri si peminta untuk dijualkan oleh Rasul. Disinilah kemudian tercermin transaksi yang dikenal masyarakat modern dengan sebutan lelang.

Pada proses lelang tersebut maka harga suatu barang akan naik terus sesuai dengan tawaran yang datang dari pembeli. Misalanya jika suatu barang akan dijual maka akan ditetapkan sebuah harga dan akan diinformasikan siapa yang mau membeli ini dengan harga sekian. Ketiaka ada yang mampu makan lelangannya dinaikkan lagi, kemudia ketika ada yang menawari di tawaran kedua, maka sipenjual akan menaikkan lagi tawaran diatas tawaran yang diminta. Dan begitu seterusnya sampai batas harga yang wajar.

Dari hasil tersebut menjadi cikal bakal adanya modal untuk laki-laki tersebut bisa bekerja dan menghidupi keluarganya. Disi Rasulullah memperdayakan laki-laki tersebut untukmenjadi penjual kayu dengan modal membeli kampak yang digunakan untuk mengumpulkan kayu bakar untuk dijual . Sabda Rasul: "Ini lebih baik bagimu daripada sikap meminta-minta datang sebagai noktah di wajahmu pada Hari Kiamat. Sesungguhnya sikap meminta-minta tidak layak kecuali untuk tiga orang, yaitu untuk 
orang fakir dan miskin, atau orang yang memiliki hutang sangat berat, atau orang yang menanggung diyah (sementara ia tidak mampu membayarnya)."14

Jadi pemberdayaan masyarakat bukanlah hal yang baru untuk dilakukan, dari Hadis diatas didapatkan bahwa : pemberdayaan ekonomi masyarakat dengan cara : 1 . Sadarkan pentingnya pemberdayaan ekonomi masyarakat, 2. Sosialisasikan bahwa modal uang bukanlah hal yang utama, 3. Lihat potensi masyarakat, 4. Ubah aset yang tidak produktif, 5. Sediakan wadah pemasaran, 6. Transparan dan atur keuangan dengan baik, 7. Tunjuk pendampingan usaha yang profesional 8. Efektifkan waktu, 9. Motivasi untuk berubah.

b. Pemberdayaan Masyarakat Masa Kekhalifahan

Pemberdayaan masyarakat pada masa kekhalifahan juga sudah dilakukan terdahulu oleh khalifah, Abu Bakar, Umar, Utsan, dan Ali khususnya pemberdayaan bidang pendidikan. Kalau merujuk pada sejarah hidup pada khalifah Abu Bakar ini maka sesungguhnya masih belum terlalu jauh dari masa kenabian atau masa nabi masih menjadi pemimpin. Kalau dilihat dari semua aspek maka tidaklah salah kalau masa khalifah Abu Bakar ini menjadi masa transisi. Hal tersebut dibuktikan dengan pola pendidikan, materi pendidikan, dan lembaga pendidikan yang tidak jauh berbeda pada masa Nabi. Pemberdayaan masyarakat pada masa kekhalifahan yang pertama terlihat dari keberhasilan khalifah umar menugaskan panglima untuk mendirikan masjid. Masjid tersebut kemudian menjadi muara pemberdayaan masyarakat bidang pendidikan. ${ }^{15}$

Wujud pemberdayaan masyarakat yang lain adalah dengan memberdayakan disetiap daerah guru yang akan mengajarkan Tauhid, al-Qur'an, Akhlak, Ibadah, dan fiqih kepada masyarakat banyak terutama mereka-mereka yang muallaf. Pada masa khlaifah selanjutnya juga demikian, pada masa ini cenderung melanjutkan apa yang telah dirintis oleh khalifah sebelumnya. Diberikannya kebebasan kepada para sahabat yang alim untuk menetap di berbagai daerah sehingga tersebarnya Islam semakin luas. Yang menjadi target dalam pemberdayaan masyarakat antara lain orang tua, orang dewasa, anak-anak, orang yang muallaf maupun yang bukan muallaf. Dan terkhusu bagi orang-orang yang menuntut ilmu secara luas.

\footnotetext{
${ }^{14}$ https://carihadis.com/Sunan_Abu_Daud/1398.

${ }^{15}$ Nizar Samsul, Sejarah Pendidikan Islam (Menelusuri jejak sejarah pendidikan Era Rasulullah Sampai Indonesia) (Jakarta: Kencana Prenada Media Grup, 2009), 47.
} 
Dan masa khalifahan yang terakhir pada masa pemerintahan sayyidina Ali bin Abi Thalib, sudah diguncang peperangan dengan Aisyah (istri Nabi) beserta Talhah dan Abdullah bin Zubair karena kesalahfahaman dalam menyikapi pembunuhan terhadap Usman. Peperangan diantara mereka disebut perang Jamal (unta) karena Aisyah menggunakan kendaraan unta. Setelah berhasil mengatasi pemberontakan Aisyah, muncul pemberontakan lain, sehingga masa kekuasaan khalifah Ali tidak pernah mendapatkan ketenangan dan kedamaian. ${ }^{16}$ Dengan demikian maka kegiatan pendidikan Islam mendapat hambatan dan gangguan. Namun, secara umum pola pendidikan pada masa Khulafaur rasyidin tidak jauh berbeda dengan masa Nabi yang menekankan pada pengajaran baca tulis dan materi tentang ajaran-ajaran Islam yang bersumber pada AlQurean dan Hadis Nabi”.

\section{Relevansi Pemberdayaan Masyarakat di lembaga pendidikan}

Secara garis besar, lembaga pendidikan dapat digategorikan menjadi tiga kategori yaitu kategori lembaga pendidikan keluarga, lembaga pendidikan sekolah dan lembaga pendidikan Masyarakat. Secara sosiologis lembaga pendidikan merupakan tiga komponen dalam satu sistem, "yaitu sistem pendidikan nasional. Dalam UU sistem pendidikan nasional No. 20 tahun 2003, pasal 9, bahwa masyarakat berhak untuk berperan serta dalam perencanaan, pelaksanaan, pengawasan, dan evaluasi program. ${ }^{17}$ Peraturan pemerintah No. 39 tahun 1992 tentang peran serta masyarakat dalam Sistem Pendidikan Nasional". ${ }^{18}$ Masyarakat adalah "komponen pendidikan nasional yang sangat berpengaruh dalam pengembangan pendidikan. Adapun masalah mutu pendidikan, bukan hanya masyarakat yang bertanggung jawab, tetapi keluarga dan sekolah juga ikut bertanggung jawab”. Menurut Hadari Nawawi dalam Zuharini dkk., yang bertanggung jawab atau maju mundurnya kualitas pendidikan ada pada pundak keluarga, sekolah, dan masyarakat. ${ }^{19}$

Jadi relevansi pemberdayaan masyarakat di lembaga pendidikan dapat dilihat pada tiga aspek penting yaitu lembaga pendidikan keluarga, lembaga pendidikan

\footnotetext{
${ }^{16}$ Supardi Ahmad Sukarno, Sejarah dan Filsafat Pendidikan Islam (Bandung: Angkasa, 1990), 50.

${ }^{17}$ Dede Rosyada, Paradigma Pendidikan Demokratis: Jakarta: Kencana Prenada Media Group (Jakarta: Kencana Prenada Media Group, 2007), xii.

${ }_{18}^{18}$ H Munandir, Ensiklopedia Pendidikan (Malang: UM-Press, 2001), 363.

19 Abu Ahmadi dan Nur Uhbiyati, Zuhairini. Dkk, Filsafat Pendidikan Islam (Jakarta: Bumi Aksara, 1995), 98.
} 
sekolah dan lembaga pendidikan masyarakat. Ketiga-tiganya penting untuk mewujudkan pemberdayaan masyarakat dibidang pendidikan.

a. Lembaga Pendidikan Keluarga

Lembaga ini merupakan lembaga yang pertama yang dijadikan tempat oleh seorang anak untuk belajar. Ibu akan menjadi madrosatul ula bagi anak, dengannya seorang anak belajar akan belajar tentang banyak hal. Dalam keluarga inilah yang akan menjadi dasar peletakan kepribadian anak. Pemberdayaan dalam lembaga pendidikan keluarga dapat dijumpai dari bagaiama seorang kepala keluarga memberdayaakan anggota keluarga untuk melakukan hal-hal yang positif demi kemajuan institusi keluarga ke arah yang lebih baik serta menjamin keberlansungan pembekalan kekuatan pendidikan maupun kekuatan ekonomi.

Pemberdayaan dalam lembaga pendidikan keluarga dapat dijumpai dari bagaimana seorang kapala keluarga memberdayakan anggota keluarga untuk melakukan hal-hal yang positif demi kemajuan institusi keluarga ke arah yang lebih baik serta menjamin keberlansungan pembekalan kekuatan pendidikan maupun kekuatan ekonomi.

\section{b. Lembaga Pendidikan Sekolah}

Sekolah merupakan salah satu lembaga pendidikan yang akan dijalani oleh seorang. Semakin banyak kebutuhan anak, maka orang tua akan menyerahkan tanggung jawab sebagian besar pada lembaganya. Sekolah sebagai pembantu keluarga dalam mendidik anak. Sekolah memberikan pendidikan dan pengajaran kepada masyarakat tentang apa yang tidak didapatkan dalam lembaga pendidikan keluarga. Pemberdayaan masyarakat dalam lembaga pendidikan dapat dilakukan dengan melibatkan masyarakat sekitar dalam merencanakan, mengembangakan, melakasanakan dan mengawasi keberlansungan pendidikan di lembaga pendidikan.

Hal tersebut bisa dilihat dari adaya komite sekolah dalam struktur organisasi lembaga pendidikan yang melibatkan masyarakat dan orang tua siswa dalam keanggotaannya. Selain mengawasi kebijakan dan proses di dalam lembaga pendidikan, koite sekolah juga berperan penting untuk pengembangan sekolah baik secara fisik maupun non fisik. Pengembangan dalam penguatan ilmu pengetahuan maupun pengembangan dalam ekonomi dan pendanaan lembaga pendidikan. 


\section{c. Lembaga Pendidikan Masyarakat}

Lemaga pendidikan masyarakat merupaan lembaga pendidika yang ketiga. Lembaga pendidikan ini dimulai sejak anak anak hingga ia dewasa. Ragam pendidikan yang diterima anak didik dan masyarakat ini banyak dan meliputi berbagai macam bidang baik pembentukan kebiasaan, pembentukan pengetahuan, sikap dan minat. Pendidikan di lembaga pendidikan masyarakat ini hakikatnya pembelajaan yang dilaksanakan. Dilembaga pendidikan masyarakat secara tidak lansung pemberdayaan masyarakat sudah sangat jelas dijumpai ditengah tengah keberagaman namun belum secara maksimal dan merata. Baik dalam hal pemberdayaan masyarakat di bidang penguatan ilmu pengetahuan maupun pemberdayaan masyarakat di bidang ekonomi dan kesejahteraan.

Dari ketiga aspek penting relevansi lembaga pendidikan dalam pemberdayaan masyarakat diatas kaitannya dengan penguatan ilmu pengetahuan, dan ekonomi maka penulis merekomendasikan untuk bersama-sama memaksimalkan pemberdayaan masyarakat dengan meningkatkan penguatan limu pengetahuan dan penguatan ekonomi melakui ketigaya dengan harapan pemberdayaan masyarakat akan mendapatkan perhatian secara maksimal dari semua kalangan serta dilakuakn secara merata.

\section{KESIMPULAN}

Kesimpulan dari penelitian ini adalah setelah menginventarisir Hadis-Hadis tentang pemberdayaan masyarakat maka didapatkan 129 Hadis dari 18 kitab Hadis. Pemberdayaan ekonomi masyarakat dilakukan dengan cara: Sadarkan pentingnya pemberdayaan ekonomi masyarakat, Sosialisasikan bahwa modal uang bukanlah hal yang utama, Lihat potensi masyarakat, Ubah aset yang tidak produktif, Sediakan wadah pemasaran, Transparan dan atur keuangan dengan baik, Tunjuk pendampingan usaha yang profesional, Efektifkan waktu, Motivasi untuk berubah. Pemberdayaan ekonomi masyarakat pada masa nabi tercermin dalam Hadis Abu Daud, sedangkan pemberdayaan ilmu dalam Hadis Ahmad.

Sedangkan pemberdayaan masyarakat masa kekhalifahan: pola pendidikan, materi pendidikan, dan lembaga pendidikan, pendidikan Islam, akhlak, ibadah, kesehatan. Membangun masjid, menunjuk guru-guru, mengajarkan isi AlQur'an dan ajaran Islam lainnya. Para guru bisa memilih tempat yang mereka inginkan untuk 
memberikan pendidikan kepada masyarakat. Pada masa kekhalifahan ke empat tidak lagi memikirkan masalah pendidikan karena seluruh perhatiannya ditumpahkan pada masalah keamanan dan kedamaian bagi masyarakat Islam. Adapun relevansi pemberdayaan masyarakat di lembaga pendidikan sudah sangat jelas dijumpai ditengah tengah keberagaman namun belum secara maksimal dan merata. Baik dalam hal pemberdayaan masyarakat di bidang penguatan ilmu pengetahuan maupun pemberdayaan masyarakat di bidang ekonomi dan kesejahteraan

\section{Daftar Rujukan}

Adi, Isbandi Rukminto. Pemberdayaan, pengembangan masyarakat dan Intervensi Komunitas. Jakarta: Lembaga Penerbit FEUI, 2003.

Ahmadi, Abu, dan Nur Uhbiyati. Zuhairini. Dkk, Filsafat Pendidikan Islam. Jakarta: Bumi Aksara, 1995.

Baihaki, Imam. "Potret Penguburan Janazah Dalam Islam Merupakan Bentuk Kepedulian Sosial Dunia-Akhirat." Al Bayan: Jurnal Ilmu Al Qur'an dan Hadist 4, no. 1 (2021): 67-77.

Dozan, Wely. "Hadis-Hadis Tahlilan: Analisis Konflik dan Nilai-Nilai Sosial Masyarakat." Al Bayan: Jurnal Ilmu Al Qur'an dan Hadist 3, no. 2 (2020): 195-211.

Fauzan, Abdul Azis Al. Fikih Sosial: Tuntunan dan Etika Hidup Bermasyarakat, terjemahan Iman Firdaus dan Ahmad Salahudin. Jakarta Timur: Qisthi Press, 2007.

https://carihadis.com/Musnad_Ahmad/18723, t.t.

https://carihadis.com/Sunan_Abu_Daud/1398, t.t.

Ismail, M Syuhudi. Metodologi Penelitian Hadis Nabi. Jakarta: PT. Bulan Bintang, 1992.

Khon, Abdul Majid. Ulumul hadis. Jakarta: Amzah, 2012.

Kurniati, Mia. "Peran Kepemimpinan Kyai Dalam Mendidik Dan Membentuk Karakter Santri Yang Siap Mengabdi Kepada Masyarakat.” Al Bayan: Jurnal Ilmu Al Qur'an dan Hadist 2, no. 2 (2019): 193-202.

Munandir, H. Ensiklopedia Pendidikan. Malang: UM-Press, 2001.

Nasrul, Effendy. Dasar-dasar keperawatan kesehatan masyarakat. Jakarta: EGC, 1998. 
Rahman, Fatchur. Ikhtisar Musthalahul Hadis. Bandung: PT. AL-Ma'arif, 1974.

Rahman, Muhammad S. "Kajian Matan dan Sanad Hadis dalam Metode Historis." Jurnal Ilmiah Al-Syir'ah 8, no. 2 (2016).

Rosyada, Dede. Paradigma Pendidikan Demokratis: Jakarta: Kencana Prenada Media Group. Jakarta: Kencana Prenada Media Group, 2007.

Samsul, Nizar. Sejarah Pendidikan Islam (Menelusuri jejak sejarah pendidikan Era Rasulullah Sampai Indonesia). Jakarta: Kencana Prenada Media Grup, 2009.

Sany, Ulfi Putra. "Prinsip-Prinsip Pemberdayaan Masyarakat Dalam Perspektif Al Qur'an.” Jurnal Ilmu Dakwah 39, no. 1 (2019): 32-44.

Sukarno, Supardi Ahmad. Sejarah dan Filsafat Pendidikan Islam. Bandung: Angkasa, 1990. 